\title{
PENINGKATAN KEMAMPUAN MENULIS PUISI SISWA KELAS V SD NEGERI SUMBERSARI III MALANG DENGAN STRATEGI PEMETAAN PIKIRAN
}

\author{
oleh Elfia Sukma \\ FIP Universitas Negeri Padang
}

\begin{abstract}
This article is about a classroom action research conducted to improve the ability of students in Grade V, Elementary School of Sumbersari III, Malang, in writing poetry by means of a mind-mapping strategy. With the low level of the students' ability in writing poetry as the background of the research, the research was conducted in two cycles, each of which consisted of the stages of planning and implementation. Each stage consisted of the activities of (a) finding and developing ideas, (b) writing, (c) presentation, and (d) evaluation. The results of the research indicate that the use of the mind-mapping strategy could improve the students' ability in writing poetry.
\end{abstract}

Keywords: strategy, mind mapping, writing poetry, learning, elementary school

\section{A. PENDAHULUAN}

Pembelajaran apresiasi sastra bertujuan agar siswa mampu mengapresiasi dan berekspresi sastra melalui kegiatan mendengarkan, menonton, membaca, dan melisankan hasil sastra berupa dongeng, puisi, dan drama pendek, serta menuliskan pengalaman dalam bentuk cerita dan puisi (Depdiknas, 2003). Ini berarti bahwa siswa diharapkan mampu berapresiasi sastra secara aktif dan kreatif.

Kegiatan berapresiasi sastra sangat bermanfaat bagi siswa. Manfaat berapresiasi sastra pada siswa adalah agar mampu secara kreatif melakukan pengenalan realitas, pengembangan kemampuan berbahasa, pengembangan kemampuan memahami bentuk-bentuk hubungan sosial, maupun pengembangan kemampuan memahami diri sendiri dan orang lain. Sebagaimana dikatakan Stewig (dalam Aminuddin, 2001: 16) bahwa siswa mengapresiasi sastra untuk mendapatkan kesenangan. Secara psikologis, aktivitas mengapresiasi sastra tersebut juga akan mengasah kepekaan emosi, mengembangkan daya imajinasi, dan memperkaya skemata siswa.

Dalam mencapai tujuan dan manfaat pembelajaran apresiasi sastra, diperlukan pembelajaran yang efektif. Dalam pembelajaran yang efektif, peranserta guru sangat menentukan. Sebagaimana dikatakan Aminuddin (1990:207) bahwa ada dua tugas guru dalam kegiatan apresiasi, yaitu (1) mengembangkan pengetahuan dan pengalaman (skema simbolik) siswa, dan (2) membimbing cara berpikir siswa. Di dalam melaksanakan pengembangan pengetahuan dan pengalaman siswa, guru berperan penting untuk mengembangkan pengetahuan dan pengalaman siswa dalam kehidupan sehari-hari, serta membimbing siswa ke arah berpikir kritis terhadap hal-hal yang berkaitan dengan pengalaman siswa.

Menulis puisi merupakan bagian dari pembelajaran apresiasi sastra yang perlu dimiliki siswa. Kompetensi dasar menulis puisi di kelas V semester 2 sekolah dasar berbunyi "menulis puisi bebas" dengan indikator 
pembelajaran, yaitu "siswa mampu menentukan gagasan pokok puisi, menentukan hal-hal yang menarik dari pengalaman dan mampu menulis puisi bebas" (Depdiknas, 2003:173). Kompetensi dasar tersebut mengisyaratkan sebuah proses. Melalui tahapan poses menulis, siswa diajak dan diarahkan untuk menemukan hal-hal yang dipikirkannya. Hal-hal yang dipikirkan siswa tidak lepas dari pengalaman dan pengetahuan yang dimilikinya. Tahapan-tahapan yang bermula dari pemunculan gagasan sampai menjadi suatu karya disebut dengan proses menulis kreatif. Menulis puisi termasuk ke dalam menulis kreatif.

Menurut Maybury (dalam Percy, 1981:1) menulis kreatif dapat mendorong anakanak untuk menggunakan segala kemampuan mereka yang berupa gagasan, kesan-kesan, perasaan, harapan-harapan, dan imajinasi mereka serta bahasa yang dapat digunakan untuk menulis komentar mereka. Jackson (dalam Percy, 1981:2) mengemukakan bahwa menulis kreatif merupakan kemampuan untuk mengekspresikan imajinasi dalam rangka menciptakan sebuah gambar dalam pikiran seseorang. Definisi tersebut menunjukkan bahwa menulis puisi sebagai bagian dari kegiatan menulis kreatif merupakan salah satu cara untuk mengekspresikan gagasan, perasaan, dan pengalamannya dengan menggunakan bahasa yang indah.

Dengan menulis puisi, siswa dapat mengekspresikan gagasan, perasaan, serta pengalamannya secara puitik. Guru dapat membantu siswa untuk memunculkan dan mengembangkan gagasan, kemudian mengorganisasikannya menjadi puisi. Dengan demikian, kegiatan menulis puisi memerlukan beberapa kemampuan, misalnya kemampuan memunculkan gagasan, kemampuan mengembangkan gagasan, kemampuan menggunakan pilihan kata secara cermat, serta mengorganisasikannya sehingga menghasilkan puisi yang bermakna.

Kelemahan pembelajaran sastra terdapat pada kemampuan guru dalam melaksanakan pembelajaran. Menurut Kasnadi
(Kompas (online), 19 Januari 2002) mengapa sastra tidak diminati para siswa sehingga muncul sinyalemen: sastra itu sulit, sastra itu tidak menarik, sastra itu membosankan, sehingga siswa memvonis untuk menjauhi sastra. Hal itu adalah karena ketidakmampuan guru menyajikan pembelajaran sastra itu menjadi sesuatu yang menarik. Guru masih memberikan hapalan-hapalan kepada anak, seperti judul hasil sastra dan pengarangnya serta angkatan kesusastraan. Padahal tujuan pembelajaran sastra adalah memupuk apresiasi anak terhadap hasil sastra.

Berdasarkan studi pendahuluan yang penulis lakukan melalui tes pada hari Rabu, tanggal 29 September 2004, di kelas V SD Negeri Sumbersari III Malang, diperoleh fakta bahwa kemampuan siswa dalam menulis puisi masih kurang memuaskan. Dari analisis hasil tes menulis puisi, ditemukan bahwa (1) kandungan isi yang tertuang di dalam bait demi bait kurang sesuai dengan judul, dan (2) siswa banyak menggunakan kata mubazir, sehingga puisi kurang bermakna.

Kemudian hasil wawancara peneliti dengan guru kelas V SD Negeri Sumbersari III Malang diperoleh informasi bahwa guru kurang efektif dalam memilih dan menerapkan strategi yang tepat dalam menulis puisi. Kekurangefektifan itu terlihat dari temuan berikut. Guru langsung menugasi masingmasing siswa membuat judul puisi. Guru tidak membimbing siswa terlebih dahulu memunculkan gagasan, sehingga siswa menjadi bingung dan membutuhkan waktu yang lama untuk memulai menulis puisi. Dalam mengembangkan gagasan, guru juga kurang membimbing siswa. Guru hanya menugasi siswa mengkhayal sesuai dengan judul yang sudah mereka tulis sehingga siswa mengalami kesulitan dalam mengembangkan gagasan dan hasil pengembangan gagasan yang dibuat siswa menjadi tidak mempunyai makna karena banyak mengungkapkan hal-hal yang mubazir. Sebagai penulis puisi pemula, sebaiknya guru membimbing siswa menulis puisi, mulai dari tahap memunculkan gagasan, mengembangkan gagasan sampai kepada tahap menulis puisi 
secara utuh. Akibatnya, kemampuan siswa menulis puisi masih kurang memuaskan.

Permasalahan tersebut perlu ditanggulangi lewat pembelajaran menulis puisi. Salah satu upaya yang dapat dilakukan adalah dengan menggunakan strategi pemetaan pikiran. Strategi pemetaan pikiran adalah suatu teknik grafis untuk mempresentasikan gagasan dengan menggunakan kata-kata, imaji, lambang, dan warna (Buzan, 2004). Pemetaan pikiran didasarkan pada pola-pola penemuan di alam dan penelitian tentang bagaimana manusia berpikir serta menggunakan pikirannya.

Pemetaan pikiran dapat meningkatkan kualitas pikiran. Ia membantu sistem berpikir, menyediakan suatu pandangan representasi visual, memperlihatkan kaitan gagasan dan sintesisnya serta memfasilitasinya (Wycoff, 2004). Ia membantu siswa berpikir kreatif, membolehkan siswa untuk mengakses intelegensi multipel dan menghasilkan gagasan-gagasan baru. Pemetaan pikiran membantu siswa meng-organisasikan gagasan yang ada dalam pikiran siswa dan orang lain. Penciptaan peta pikiran dapat meningkatkan ingatan dan pembelajaran. Pemetaan pikiran sangat baik untuk menghasilkan dan menata gagasan sebelum mulai menulis.

Pemetaan pikiran sangat berperan di dalam penulisan puisi, karena pemetaan pikiran merupakan proses kreatif untuk melahirkan sesuatu. Pemetaan pikiran dapat membantu siswa berpikir kreatif sehingga di dalam menulis puisi, pemetaan pikiran menjadi sarana yang ampuh untuk memunculkan, mengembangkan, dan menyempurnakan gagasan. Pemetaan pikiran membantu siswa mengorganisasikan gagasan yang ada dalam pikiran siswa.

\section{B. METODE PENELITIAN}

Penelitian ini merupakan penelitian tindakan kelas yang termasuk jenis penelitian kualitatif. Penelitian tindakan kelas merupakan bentuk penelitian yang bersifat reflektif dengan melakukan tindakan-tindakan tertentu untuk memperbaiki atau meningkatkan praktik- praktik pembelajaran di kelas secara lebih profesional. Oleh sebab itu, penggunaan stategi pemetaan pikiran dalam pembelajaran menulis puisi dilakukan sebagai upaya untuk meningkatkan kemampuan menulis puisi pada siswa kelas V SD Negeri Sumbersari III Malang.

Penelitian dimulai dengan melakukan studi pendahuluan terhadap pembelajaran menulis puisi di kelas V SD Negeri Sumbersari III Malang. Hal ini dilakukan untuk mengetahui permasalahan yang dihadapi guru dan siswa berkaitan dengan pembelajaran menulis puisi. Berdasarkan studi pendahuluan, dilakukan diskusi dengan guru kelas $\mathrm{V}$ untuk melaksanakan tindakan dalam rangka meningkatkan kemampuan siswa menulis puisi. Langkah berikutnya adalah pelaksanaan tindakan yang diawali dengan perencanaan tindakan, pelaksanaan, pengamatan, dan refleksi.

Perencanaan tindakan disusun secara kolaboratif antara peneliti dan guru. Langkahlangkah yang dilakukan adalah sebagai berikut: (1) melakukan diskusi untuk menyamakan persepsi tentang strategi pemetaan pikiran, (2) menyusun rancangan tindakan berupa model pembelajaran, (3) mempersiapkan instrumen penelitian, (4) melakukan pelatihan dengan guru dalam melaksanakan pembelajaran menulis puisi dengan strategi pemetaan pikiran, dan (5) menyusun jadwal pelaksanaan tindakan.

Penelitian ini dilakukan dalam dua siklus. Setiap siklus dilaksanakan dua kali pertemuan. Pertemuan pertama tahap pemunculan dan pengembangan gagasan, pertemuan kedua tahap penulisan, dan pertemuan ketiga tahap penyajian. Alokasi waktu yang digunakan oleh masing-masing siklus berbeda sesuai dengan hasil refleksi. Siklus I dengan alokasi waktu $2 \times 40$ menit sedangkan siklus II $3 \times 40$ menit untuk satu kali pertemuan.

Pengamatan dalam pembelajaran menulis puisi dengan menggunakan strategi pemetaan pikiran dilakukan bersamaan dengan pelaksanaan tindakan. Dalam kegiatan ini, 
peneliti dan guru berusaha mengenal, merekam, dan mendokumentasikan semua indikator proses, perubahan yang terjadi, baik yang disebabkan oleh tindakan perencanaan maupun dampak intervensi dalam pembelajaran menulis puisi. Keseluruhan hasil pengamatan direkam dalam bentuk lembaran observasi. Pengamatan dilakukan pada setiap siklus. Pengamatan yang dilakukan pada satu siklus dapat mempengaruhi penyusunan tindakan pada siklus selanjutnya. Hasil pengamatan ini kemudian didiskusikan dengan guru dan diadakan refleksi untuk perencanaan siklus berikutnya.

Data dalam penelitian ini berupa data verbal dan data nonverbal. Data verbal ialah seluruh data yang terkait dengan proses pembelajaran maupun hasil pembelajaran menulis puisi dengan strategi pemetaan pikiran pada setiap tahap. Data nonverbal berupa fotofoto kegiatan pembelajaran dan gambar untuk pembangkitan skemata siswa. Sumber data penelitian ini adalah siswa kelas V SDN Sumbersari III Malang serta guru yang terlibat dalam proses pembelajaran menulis puisi dengan menggunakan strategi pemetaan pikiran.

Analisis data menggunakan model alir yang dikembangkan oleh Miles dan Huberman (1992:15-20) yang terdiri atas tiga tahap, yaitu (1) reduksi data, (2) penyajian data, dan (3) penarikan simpulan atau verifikasi. Analisis data tersebut dilakukan selama dan sesudah penelitian, mulai dari tahap pemunculan gagasan, pengembangan, penulisan, dan penyajian. Data yang diperoleh dari tiap teknik pengumpulan data saling melengkapi antara satu dengan yang lainnya.

Penarikan simpulan dilakukan dengan cara menafsirkan makna data yang tersaji. Sebelum dilakukan simpulan akhir, terlebih dahulu dilakukan simpulan sementara. Hasil penafsiran makna data yang tersaji diverifikasi untuk memperoleh simpulan akhir yang dapat dipercaya. Kegiatan verifikasi dilakukan dengan uji keabsahan temuan yang telah ditentukan.

Penelitian ini bertujuan untuk meningkatkan kemampuan siswa menulis puisi dengan menggunakan strategi pemetaan pikiran di SDN Sumbersari III Malang. Penelitian dilakukan melalui dua siklus, hasil belajar yang diharapkan adalah "siswa mampu menuangkan gagasan dalam bentuk puisi bebas". Hasil belajar tercermin dalam indikator-indikator pembelajaran yaitu (1) menentukan gagasan pokok, (2) mengembangkan gagasan pokok, (3) mengorganisasikan menjadi puisi, dan (4) menyajikan puisi. Untuk mencapai indikator, pembelajaran dibagi menjadi empat tahap kegiatan, yaitu (1) tahap pemunculan gagasan, (2) tahap pengembangan gagasan, (3) tahap penulisan dan (4) tahap penyajian.

Pada siklus pertama, guru melakukan tindakan selama 3 kali pertemuan dengan tema lingkungan keluarga. Pertemuan pertama tahap pemunculan dan pengembangan gagasan. Pertemuan kedua tahap penulisan dan pertemuan ketiga tahap penyajian. Masingmasing tahap menggunakan waktu $2 \times 40$ menit.

\section{HAS I L PENELITIAN DAN PEMBAHASAN}

\section{Hasil Penelitian}

Hasil penelitian siklus pertama pada tahap pemunculan dan pengembangan gagasan menunjukkan bahwa siswa telah mampu memunculkan lebih dari tiga gagasan yang akan dijadikan sebagai gagasan pokok. Namun, pada tahap pengembangan gagasan siswa masih kesulitan menguraikan gagasan pokok menjadi gagasan yang lebih kecil. Gagasan yang dibuat masih bersifat umum. Di samping itu, sebagian siswa masih menggunakan kalimat untuk menuliskan gagasan. Penggunaan spidol untuk mengembangkan gagasan masih terlihat kacau. Kesulitan ini disebabkan guru belum optimal melaksanakan pemodelan dan penggunaan waktu yang belum efisien. Pada tahap pemodelan siswa belum dilibatkan menuliskan gagasan, guru belum menggali imaji siswa secara optimal, dan guru belum menggunakan gambar.

Pada tahap penulisan guru belum melaksanakan pemodelan penulisan puisi 
secara optimal. Akibatnya sebagian siswa masih kesulitan mengembangkan gagasan yang berupa kata kunci menjadi kalimat. Kemudian pada tahap menata kalimat menjadi puisi siswa juga mengalami kesulitan. Sebagian kalimat yang dibuat siswa kurang sesuai dengan judul. Sehingga puisi yang ditulis siswa kurang bermakna. Secara umum pemenggalan larik telah dilakukan secara cermat dan penggunaan pilihan kata telah tepat dan wajar. Namun penggunaan imaji masih kurang bervariasi sehingga puisi yang ditulis siswa monoton.

Pada kegiatan perevisian, siswa masih tampak kesulitan merevisi puisi temannya. Siswa tampak bermain-main, kurang terbuka atau enggan menukarkan tugas dengan temannya, dan ada sebagian kecil yang belum selesai mengerjakan sehingga menganggu kegiatan perevisian. Kesulitan ini disebabkan guru belum memodelkan cara merevisi puisi.

Pada siklus kedua, guru melakukan tindakan sama dengan sikus pertama. Namun pada siklus ini jumlah jam pada masing-masing tahap ditambah satu jam pelajaran menjadi $3 \times 40$ menit.

Hasil penelitian pada tahap pemunculan dan pengembangan gagasan menunjukkan siswa telah mampu memunculkan lebih dari tiga gagasan pokok. Gagasan pokok yang dibuat siswa lebih bervariasi dibandingkan dari pada siklus pertama. Hal ini disebabkan guru telah menyediakan gambar lebih banyak dan bervariasi.

Pengembangan gagasan pokok dilakukan dengan menuliskan gagasan pokok dan gambar di tengah kertas. Kemudian dengan mengamati dan merenungkan gagasan pokok dan gambar siswa mengembangkan gagasan pokok tersebut mulai dari gagasan terdekat. Pengembangan gagasan yang dilakukan siswa rata-rata berkualifikasi sangat baik. Melalui pemetaan pikiran siswa mampu mengembangkan gagasan secara rinci dan logis serta mampu menggunakan imaji dan gambar.

Pembelajaran menulis puisi pada tahap penulisan dilakukan dengan mempedomani pemetaan pikiran yang sudah dibuat siswa.
Kegiatan dimulai dengan menulis judul puisi yang diambil dari gagasan pokok atau hasil perenungan siswa terhadap peta pikiran. Kemudian menyusun kata-kata dengan urutan ke bawah. Kata-kata tersebut kemudian dikembangkan menjadi kalimat. Pengembangan kata menjadi kalimat selalu disesuaikan dengan judul. Selanjutnya kalimat tersebut ditata menjadi larik-larik puisi. Puisi yang telah dibuat kemudian direvisi. Puisi yang dibuat siswa berdasarkan pemetaan pikiran rata-rata berkualifikasi sangat baik Siswa tidak mengalami kesulitan untuk memulai menulis puisi. Isi puisi sudah sesuai dengan judul, pemenggalan larik dilakukan dengan cermat, penggunaan diksi sudah tepat dan wajar, dan sebagian siswa telah mampu menggunakan imaji secara bervariasi.

Pembelajaran menulis puisi pada tahap penyajian dilakukan dengan menugasi siswa membacakan puisi dan memajangkannya. Kegiatan membaca puisi dilakukan dangan menugasi siswa membaca secara bergiliran ke depan kelas. Siswa tampak gembira dan bangga membacakan puisi yang dibuatnya. Kegiatan membaca puisi disertai dengan mengomentari pembacaan puisi. Puisi yang telah dibaca kemudian dipajang. Kegiatan membaca puisi rata-rata berkualifikasi baik. Siswa mampu melafalkan bunyi bahasa dengan tepat, membaca puisi dengan tepat sesuai dengan tinggi rendah irama puisi, dan sudah mampu menggunakan ekspresi dengan baik sehingga pembacaan puisi menjadi hidup.

\section{Pembahasan}

Pembahasan hasil penelitian terdiri atas empat tahap, yaitu (1) tahap pemunculan gagasan, (2) tahap pengembangan gagasan, (3) tahap penulisan, dan (4) tahap penyajian. Sebelum diuraikan ketiga tahapan tersebut, terlebih dahulu dikemukakan perencanaan tindakan.

Sebelum kegiatan pemunculan gagasan dilaksanakan, terlebih dahulu siswa dipersiapkan agar dapat menerima pembelajaran dengan baik. Penyiapan siswa dirancang dengan empat deskriptor, yaitu (1) 
menyapa siswa, (2) bernyanyi bersama, (3) menjelaskan tujuan dan langkah-langkah pembelajaran, dan (4) memberi kesempatan pada siswa menanyakan hal-hal yang belum dipahami. Kegiatan penyiapan siswa, dengan cara menyapa siswa sebelum pembelajaran dimulai, sangatlah penting dilakukan guru, karena dapat menciptakan prakondisi mental siswa untuk menerima pembelajaran. Guru dapat melakukannya dengan menyapa siswa dengan ramah dan rendah hati. Dengan keramahan guru di dalam kelas, serta sikap rendah hati dari guru, siswa dapat menerima pembelajaran secara menyenangkan. Hal ini dibenarkan oleh Prijosaksono dan Sembel (2002) bahwa sikap rendah hati dapat membangun rasa menghargai orang lain. Guru dan siswa saling menghargai, baik ketika guru bertindak sebagai pengajar maupun sebagai pendengar. Begitu juga siswa sebagai subjek yang berperan aktif dalam pembelajaran maupun sebagai peserta didik di kelas.

Apalagi tingkat usia siswa yang masih duduk di sekolah dasar, sangat membutuhkan kasih sayang, bimbingan, serta motivasi dari guru, yang dianggap siswa sebagai idola mereka, serta sebagai orang tua mereka di sekolah. Dengan demikian, penyiapan siswa oleh guru dengan cara menyapa siswa, mampu menciptakan prakondisi objektif dalam mempersiapkan mental siswa untuk menerima pembelajaran. Kegiatan penyiapan siswa selanjutnya adalah mengajak siswa bernyanyi bersama. Kegiatan bernyanyi bersama mampu membuat siswa merasa nyaman dan menyenangkan dalam mempersiapkan mental untuk belajar.

Penyampaian tujuan dan langkahlangkah pembelajaran bertujuan untuk memfokuskan pikiran siswa terhadap apa yang harus dicapai dan dikuasai siswa dalam pembelajaran, agar siswa tidak mengalami kesulitan. Oleh karena itu, penyampaian tujuan dan langkah-langkah pembelajaran penting dilakukan. Menurut Kemp (1985:39) penyampaian tujuan dapat membantu dan mengarahkan siswa pada ukuran keberhasilan mata pelajaran yang telah ditetapkan. Hal ini senada dengan Degeng (1989:41) yang menyatakan bahwa penyampaian tujuan memberi pengaruh yang berarti pada kemampuan siswa dalam menampilkan perilaku belajar yang diharapkan. Dengan menyampaikan tujuan dan langkah-langkah pembelajaran kepada siswa, berarti guru bersifat terbuka. Mengajar dengan sikap terbuka berarti mengajarkan kepada siswa dua hal, yakni (1) melatih siswa melihat persoalan dari sudut pandang yang berbeda, dan (2) melatih menghargai hak orang lain untuk berbeda pendapat dengannya, serta mau mempertimbangkan alasan yang diajukan orang (Alwasilah, 1997:145). Dengan ini diharapkan siswa mau memahami dan mengerjakan tugas-tugas yang diberikan.

Setelah menjelaskan tujuan dan langkah-langkah pembelajaran yang akan dilaksanakan, guru perlu memberi kesempatan pada siswa untuk menanyakan hal-hal yang belum dipahami. Hal ini penting dilakukan agar pembelajaran dapat dilaksanakan dengan optimal.

Sebelum melaksanakan tahap pemunculan gagasan hingga tahap penyajian, terlebih dahulu guru melakukan pemodelan untuk masing-masing tahap tersebut. Hal ini sejalan dengan pendapat Aminuddin (1999:18) yang menyatakan bahwa dalam pembelajaran, guru harus bertindak sebagai model, fasilitator, dinamisator, pengamat, dan peneliti dalam mengarahkan kegiatan siswa. Dalam penelitian ini terungkap bahwa guru telah melibatkan siswa dalam pemodelan. Siswa tampak aktif, antusias, dan termotivasi dalam kegiatan pembelajaran. Menurut Nurhadi dan Senduk (2003), guru bukan satu-satunya model di dalam pembelajaran. Model sebaiknya dirancang dengan melibatkan siswa.

Pada tahap pemunculan gagasan, fokus pembelajaran diarahkan untuk meningkatkan kemampuan siswa dalam memunculkan gagasan yang akan dijadikan sebagai gagasan pokok pada penulisan puisi. Pemunculan gagasan dilakukan dengan mengamati dan merenungkan gambar yang dipilih dari beberapa gambar yang ada. Menurut Syafi"'ie 
(1988) sumber penulisan dapat berasal dari pengetahuan dan pengalaman penulis sendiri, pengetahuan dan pengalaman orang lain, dan juga dapat berasal dari pengamatan, pendapat, sikap, tanggapan maupun imajinnasi penulis. Gambar yang dipilih adalah gambar yang disenangi siswa. Dengan memberi kebebasan kepada siswa untuk memilih gambar yang disenanginya, berarti siswa mempunyai pengalaman dengan gambar tersebut. Hal ini akan memudahkan siswa dalam memunculkan gagasan. Karena itu, tahap pemunculan gagasan merupakan tahap yang paling penting dalam proses pembelajaran menulis puisi.

Pada kegiatan pemunculan gagasan siswa diajak untuk menemukan hal-hal yang menarik dari gambar yang diamati dan direnungkannya. Dalam kegiatan ini, siswa dibantu oleh guru dengan mengajukan pertanyaan, baik yang berhubungan dengan gambar maupun pengalaman siswa sendiri. Siswa menuliskan hal-hal yang menarik dari gambar atau dari pengalamannya. Hal-hal menarik yang diungkapkan siswa disempurnakan, sehingga menjadi gagasan pokok. Gagasan pokok yang sudah dipilih siswa merupakan hal yang pernah dialaminya sendiri. Dengan demikian, siswa dapat memberi alasan mengapa memilih gagasan pokok tersebut, atau menceritakanya secara mendetail. Hal ini akan membantu siswa untuk mengembangkan gagasan pokok dan akhirnya menjadi sebuah puisi. Hal tersebut sejalan dengan pendapat Nurhadi (2001:1) yang mengemukakan bahwa sebaiknya guru mengaitkan antara materi yang diajarkan dengan situasi dunia nyata siswa dan mendorong siswa membuat hubungan antara pengetahuan yang dimilikinya dalam penerapan dengan kehidupan mereka sebagai anggota keluarga dan masyarakat.

Tahap pengembangan gagasan merupakan kelanjutan dari tahap pemunculan gagasan. Pada tahap ini siswa diharapkan dapat mengembangkan gagasan pokok menjadi gagasan yang lebih kecil. Dengan memilih gagasan pokok yang sesuai dengan pengetahuan dan pengalamannya, akan memudahkan siswa mengembangkannya.
Menurut Wycoff (2004) pemetaan pikiran adalah cara yang sangat baik untuk menghasilkan dan menata gagasan sebelum memulai menulis. Ini berarti bahwa dengan pemetaan pikiran, gagasan pokok yang akan dikembangkan akan dapat ditata dengan cermat.

Gagasan pokok tersebut kemudian dikembangkan dengan menggunakan peta pikiran. Kegiatan pengembangan gagasan dimulai dengan menulis gagasan pokok dan membuat gambar yang ditempatkan di tengah kertas. Hal ini, menurut Buzan (2003:38) adalah karena sebuah gambar mengandung ribuan kata, yang sekaligus menjadi fokus perhatian. Penempatan gambar di tengahtengah peta pikiran merupakan manifestasi dari cara kerja otak, yaitu bahwa otak bekerja berdasarkan asosiasi-asosiasi, serta memancar ke mana-mana.

Oleh sebab itu, di dalam pengembangan gagasan, siswa diajak mengamati dan merenungkan gagasan pokok dan gambar tersebut. Kegiatan ini dibimbing oleh guru dengan mengajukan pertanyaanpertanyaan. Hasil pengamatan dan perenungan dipetakan langkah demi langkah mulai dari gagasan yang dekat dengan gagasan pokok.

Gagasan tersebut dapat ditambah dengan imaji dan gambar. Kemudian gagasangagasan tersebut ditulis dengan menggunakan kata kunci dan dihubungkan dengan menggunakan garis nonlinier. Untuk menghubungkan gagasan, digunakan spidol warna. Hal ini terkait dengan teori Buzan (2003:38) bahwa pemetaan pikiran mengikuti cara kerja otak, yaitu asosiasi-asoisiasi, yang merupakan kata kunci, serta memancar ke mana-mana secara nonlinear. Gagasan-gagasan yang dihubungkan dengan garis nonlinier akan membantu siswa untuk menata isi puisi secara padu sehingga menjadi bermakna. Berdasarkan penjelasan di atas maka peta pikiran dibuat dalam bentuk pohon, warna, pola, dan asosiasi.

Sehubungan dengan itu, ditegaskan kembali oleh Wycoff (2004) bahwa penggunan gambar pada peta pikiran dapat membantu kita menyampaikan pesan secara visual ke dalam 
benak. Apalagi jika gambar itu disertai dengan warna. Sebab warna dapat meningkatkan kerja otak. Selanjutnya Buzan (2004) menyatakan bahwa warna dapat membuat peta pikiran tampak lebih cerah dan hidup, meningkatkan kekuatan dahsyat bagi cara berpikir kreatif dan ini juga merupakan hal yang menyenangkan. Gagasan yang berupa kata kunci dihubungan dengan menggunakan garis nonlinier. Penggunaan kata kunci menurut Wycoff (2004:71) amat penting untuk menangkap pikiran dengan cepat. Oleh karena itu, dengan menggunakan peta pikiran secara aktif, siswa dapat mengembangkan kedua belah otak untuk mengembangkan seluruh potensi pikiran yang dimilikinya. Sehingga ia dapat mengembangkan ingatan dengan baik, menata pikiran, dan meningkatkan kreativitas. Penggunaan garis nonlinier sama dengan cara kerja otak yaitu berpikir secara radial (memancar) dan eksplosif (meledak-ledak). Dryden dan Vos (2001) menyarankan agar jangan mencatat tetapi lakukan pemetaan pikiran. Menurut Buzan (dalam Wycoff, 2004:63), strategi pemetaan pikiran merupakan salah satu keterampilan yang paling efektif dalam proses berpikir kreatif. Pemetaan pikiran adalah cara yang sangat baik untuk menghasilkan dan menata gagasan sebelum mulai menulis.

Pada tahap penulisan, kegiatan pembelajaran diarahkan untuk mengorgansasikan gagasan-gagasan yang telah dikembangkan pada tahap pengembangan gagasan. Untuk mencapai tujuan tersebut, aktivitas pembelajaran diarahkan pada kegiatan penyusun gagasan yang berupa kata kunci, mengembangkan kata kunci menjadi kalimat, menata kalimat menjadi puisi, dan merevisi puisi.

Kegiatan penyusunan gagasan diawali dengan menugasi siswa menulis judul puisi. Kemudian siswa merenungkan judul puisi yang telah ditulisnya. Setelah melakukan perenungan, siswa menyusun gagasan yang berupa kata kunci. Kegiatan menyusun kata dilakukan oleh siswa sendiri. Dengan adanya sejumlah gagasan yang telah dimunculkan dengan peta pikiran, siswa tidak sulit untuk memulai menulis puisi. Menurut Wycoff (dalam Hernowo, 2003:141) pemetaan pikiran adalah cara yang sangat baik untuk menghasilkan dan menata gagasan sebelum mulai menulis.

Kata-kata yang sudah disusun kemudian dikembangkan menjadi kalimat. Pengembangan kata menjadi kalimat dapat dilaksanakan dengan menggabungkan kata dan memperluas kata menjadi kalimat. Kalimat yang dikembangkan selalu dikaitkan dengan judul. Sehingga hubungan kalimat sesuai dengan judul dan hubungan antarlarik lebih bermakna.

Kalimat yang sudah dikembangkan kemudian ditata menjadi larik-larik puisi. Penataan kalimat menjadi larik-larik puisi dilakukan dengan memendekkan kalimat panjang menjadi dua kalimat, menambah, mengurangi, atau memperbaiki. Penataan kalimat selalu memperhatikan judul, sehingga hubungan antar larik puisi bermakna.

Dari kegiatan di atas tampak bahwa dalam pembelajaran menulis puisi diperlukan ketekunan dan kesabaran guru karena siswa tidak serta merta dapat menyusun puisi sesuai dengan yang diinginkan. Sebagaimana dikemukakan Parry (dalam Santoso, 1999:12) bahwa dalam kegiatan menulis puisi, siswa diberi kebebasan menentukan langkah-langkah terbaik dalam kegiatan menulis.

Kegiatan terakhir dari tahap penulisan puisi adalah merevisi puisi yang sudah dibuat siswa. Kegiatan ini dilakukan secara berpasangan dengan menukarkan tugasnya dengan teman sebangku. Siswa saling memberi masukan terhadap puisi yang ditulisnya. Menurut Abdurrahman dan Bintoro (2000) kegiatan tersebut seiring dengan salah satu asas pembelajaran kooperatif yaitu adanya saling ketergantungan positif. Guru menciptakan suasana yang mendorong agar siswa merasa saling membutuhkan. Hubungan saling membutuhkan inilah yang disebut dengan saling ketergantungan positif. Siswa saling memberikan motivasi untuk meraih hasil belajar yang optimal.

Penyajian puisi yang telah ditulis siswa dilakukan dengan dua cara, yaitu dibacakan di 
depan kelas dan dipajang pada mading kelas. Sebagaimana yang diungkapkan oleh Tompkins (1994:24) bahwa tahap final dalam proses menulis adalah siswa mempublikasikan hasil tulisannya dan bersama-sama membahas dengan teman sejawat dan guru. Kegiatan ini dilakukan sebagai usaha agar siswa merasa karya puisi yang dihasilkannya dihargai.

Kegiatan pemodelan pembacaan puisi dilakukan dengan memberi kesempatan pada dua orang siswa untuk membaca puisi di depan kelas. Selesai membaca, guru meminta komentar siswa mengenai cara pembacaan puisi teman mereka tersebut. Kemudian guru menjelaskan hal-hal yang perlu diperhatikan dalam membaca puisi. Setelah kegiatan pemodelan selesai, siswa membacakan puisi mereka secara bergiliran ke depan kelas. Siswa lain mengomentari puisi yang dibacakan tersebut. Akhirnya, siswa memajang puisi mereka di mading kelas. Hasil karya siswa berupa puisi yang telah dipajang tersebut kemudian dikomentari bersama-sama.

\section{PENUTUP}

\section{Simpulan}

Dari hasil penelitian tindakan kelas ini dapat disimpulkan bahwa penggunaan strategi pemetaan pikiran telah mampu meningkatkan kemampuan siswa menulis puisi di SDN Sumbersari III Malang, dengan hasil berikut. (a) pada tahap pemunculan gagasan, siswa telah mampu memunculkan gagasan yang akan dijadikan sebagai gagasan pokok, (b) pada tahap pengembangan gagasan, siswa telah mampu mengembangkan gagasan secara rinci, logis, menggunakan imaji dan gambar, (c) pada tahap penulisan, siswa telah mampu menulis judul, menyusun kata, mengembangkan kata menjadi kalimat, menata kalimat menjadi puisi dengan memperhatikan kesesuaian isi dengan judul, diksi, imaji dan enjembemen, serta merevisi puisi, dan (d) pada tahap penyajian, siswa telah mampu membaca puisi dengan memperhatikan lafal, intonasi, dan ekspresi.

\section{Saran-saran}

Disarankan kepada guru kelas V SD Negeri Sumbersari III Malang atau guru dari sekolah lain yang latar belakang siswanya dalam menulis puisi seperti atau sama dengan kondisi siswa kelas V SD Negeri Sumbersari III Malang, agar menggunakan hasil penelitian ini, yaitu menggunakan strategi pemetaan pikiran sebagai metode alternatif dalam pembelajaran menulis puisi. Guru-guru SD diharapkan agar menggunakan gambar, warna, dan garis nonlinear pada peta pikiran, karena hal tersebut dapat mengaktifkan kerja otak untuk memunculkan dan mengembangkan gagasan secara kreatif dan memudahkan siswa menata gagasan sebelum menulis puisi.

Guru-guru SD juga diminta agar membimbing siswa dalam mengembangkan gagasan. Kegiatan dapat dilakukan dengan menyuruh siswa menceritakan atau tanya jawab tentang gagasan yang akan dikembangkan. Halhal yang diceritakan tersebut kemudian dipetakan dalam bentuk peta pikiran.

Pada tahap penulisan puisi, untuk penulis pemula disarankan menggunakan langkah-langkah mengorganisasikan gagasan sebagai berikut. Menulis judul puisi, mengurutkan gagasan yang berupa kata kunci dengan urutan ke bawah, mengembangkan kata menjadi kalimat, menata kalimat menjadi puisi, dan merevisi puisi. Kegiatan ini membantu siswa mengorganisasikan gagasan menjadi puisi yang bermakna.

\section{DAFTAR PUSTAKA}

Alwasilah, A. Ch. 1997. Politik Bahasa dan Pendidikan. Bandung: Remaja Rosdakarya.

Aminuddin. 1990. Tingkat Perkembangan Anak dan Kegiatan Bersastra. Malang: PPS IKIP Malang.

Aminuddin. 2001. Karya Sastra dan Anakanak. Malang: Jurusan Sastra Indonesia, Fakultas Sastra UM. 
Buzan, T. 2003. Sepuluh Cara Jadi Orang yang Jenius Kreatif. (Alih Bahasa Susi Purwoko). Jakarta: PT Gramedia Pustaka Utama.

Buzan, T. 2004. Mind Map Untuk Meningkatkan Kreativitas. (Alih Bahasa Eric Suryaputra). Jakarta: PT Gramedia Pustaka Utama.

Degeng, I.N. 1989. Ilmu Pengajaran Taksonomi Variabel. Jakarta: P2LPTK Dirjen Dikti Depdikbud.

Depdiknas. 2003. Kurikulum 2004. Jakarta: Pusat Kurikulum.

Dryden, G. dan Vos, J. 2001. Revolusi Cara Berpikir: Keajaiban Pikiran Sekolah Masa Depan (Penerjemah: Word++Translation Service). Jakarta: Kaifa.

Kasnadi. 2001. Lingkungan sebagai Basis Pembelajaran Sastra. Kompas (online) 19/1.

Kemp, M. 1987. Watching Children Read and Write. Victoria: Deakin University.

Miles, B.M. dan Huberman, A. M. 1992. Analisis Data Kualitatif (Terjemahan Tjetjep Rohendi Rohidi). Jakarta: Penerbit Universitas Indonesia.
Nurhadi, Yasin, B., dan Senduk, A.G. 2004. Pembelajaran Kontekstual dan Penerapannya dalam KBK. Malang: Penerbit UM.

Percy, B. 1981. The Power of Creatve Writing. USA: Prentice Hall.

Prijosaksono, A. dan Sembel, R. 2002. Berbicara di Depan Publik. (Online), (http://www.sinarharapan.co.id/ekono $\mathrm{mi} / \mathrm{mandiri} / 2002 / 05 / 2 \mathrm{man} 01 . \mathrm{htm}$, diakses 17 Desember 2004).

Santoso, B. 1999. Pembelajaran Bahasa dan Sastra Indonesia: Kebebasan Berpikir Siswa. Gentengkali Edisi $V$ Th. 1999/2000: 9-13.

Syafi'ie, I. 1988. Retorika dalam Menulis. Jakarta: Depdikbud.

Tompkins, G. E. 1994. Teaching Writing Balancing Process and Product. New York: Macmillan.

Wycoff, J. 2004. Menjadi Super Kreatif Melalui Metode Pemetaan Pikiran. (Penerjemah Rina S. Marzuki). Jakarta: Kaifa. 